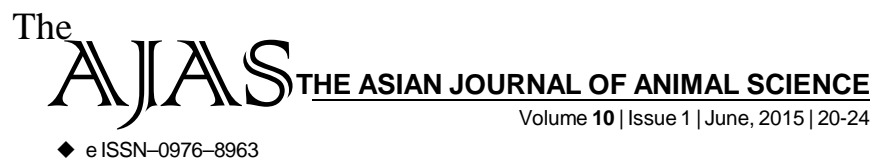

DOI : 10.15740/HAS/TAJAS/10.1/20-24 Visit us | www.researchjournal.co.in

RESEARCH ARTICLE.

\title{
Haematological and hormonal profiles of Jaffrabadi heifers on feeding regimens supplemented with rumen bypass lysine and methionine
}

M.D. ODEDRA, K. RAVIKALA, A. KHILLEDAR, N.P. SARVAIYA AND R.J. PADODARA

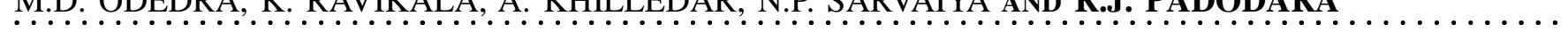

ABSTRACT...... An experiment was conducted to evaluate supplementation of rumen protected LYS (lysine) and MET (methionine) on hematological and hormonal profile in Jaffrabadi buffalo heifers. Eighteen buffalo heifers of Cattle Breeding Farm, Junagadh Agricultural University receiving either of the dietary treatments for a period of 180 days: $\mathrm{T}_{1}$-DCP requirement met through Concentrate mixture, $\mathrm{T}_{2}$-DCP requirement through cottonseed cake and concentrate mixture (50:50) and $\mathrm{T}_{3}$-In addition to DCP requirement through concentrate mixture with supplementation of rumen bypass LYS and MET @ $5.0 \mathrm{~g}$ and $2.5 \mathrm{~g} /$ day/anima, respectively. Mean RBC (red blood cell), WBC (white blood cell), HB (haemoglobin), MCV (mean corpuscular volume), MCHC (mean corpuscular haemoglobin concentration), $\mathrm{MCH}$ (mean corpuscular haemoglobin), PLT (total platelets), PCT and HCT (hematocrit / packed cell value) values were analysed. Also Plasma Estradiol and progesterone concentration was estimated by employing standard Radio Immuno Assay (R.I.A.) technique. Treatment and period has no effect in influencing the hematological values of experimental Jaffrabadi buffalo heifers. Mean values for the entire periods for Estradiol $(\mathrm{pg} / \mathrm{ml})$ and Progesterone $(\mathrm{ng} / \mathrm{ml})$ were $22.61 \pm 4.18,22.28 \pm 3.59$, $31.00 \pm 9.03 ; 0.24 \pm 0.05,0.15 \pm 0.03$ and $0.20 \pm 0.06$. There was no clear cut trend in $\mathrm{T}_{1}$ and $\mathrm{T}_{2}$ but however, in $\mathrm{T}_{3}$ there was a linear response with regard to Estradiol level. Treatment effect was

Author for Corresponding -

\section{R.J. PADODARA}

Department of Veterinary

Physiology and Biochemistry,

College of Veterinary Science,

Junagadh Agricultural University,

JUNAGADH (GUJARAT) INDIA

Email: rameshpadodara3@gmail.com

See end of the article for

Coopted authors' non-significant $(\mathrm{P}>0.05)$ at 0, 90, 180 days levels on plasma concentration of Estradiol and Progesterone. By pass LYS and MET have no effect on haematological and hormonal parameters in Jaffrabadi heifers with these feeding supplements.

KEY WORDS...... Lysine, Methionine Jaffrabadi heifers, Hematology, Estradiol, Progesterone

HOW TO CITE THIS ARTICLE - Odedra, M.D., Ravikala, K., Khilledar, A., Sarvaiya, N.P. and Padodara, R.J. (2015). Haematological and hormonal profiles of Jaffrabadi heifers on feeding regimens supplemented with rumen bypass lysine and methionine. Asian J. Animal Sci., 10(1) : 20-24.

ARTICLE CHRONICLE - Received : 04.08.2014; Revised : 11.04.2015; Accepted : 24.04.2015 